\title{
作物の環境店答に拔ける生理生態·遺伝・ 微気象モデルの融合的アプローチ
}

長谷川利拡

\section{1. はじめに}

作物の環境応答は、作目・品種の選択、栽培 暦の決定、作柄の豊凶などにかかわる最も基本 的な形質であるため、古くから多くの研究がな され、育種、栽培管理の基礎となってきた。今 後予測される気候変化および異常気象の頻発に より、作物の環境応答を理解し活用する技術は、 その重要性が増すものと考えられる。さらに、 今後の作物生産には、収量、品質、耐病虫性な どに加えて、環境負荷に関わる特性（窒素利用 効率が高い品種、メタン放出が少ない品種）な ど、多面的な形質が望まれる。このため、作物 環境応答も様々な側面についての評価が必要に なる。

これまで、作物の環境応答は、早晚性、耐冷 性、耐暑性などのように定性的に記述されるこ とが多かったが、農業分野において気候変動へ の適応、温暖化緩和技術を開発するためには、 作物の環境応答を定量的にとらえて、効率的に 改良することが望まれる。そのためには、遺伝 的要因と環境要因が作物の生理や群落の物理環 境を介して、収量・品質さらには環境負荷に及 ぼす影響を研究する分野が極めて重要になる。 本稿では、近年始まった遺伝学、作物学、農業 気象学分野における融合的なアプローチを紹介 し、分野横断型農学研究における物理学、数学 的観点の重要性を指摘する。

\section{2. これまでの作物収量予測への アプローチ}

作物収量の予測は、国レベルの需給見通し や食糧政策の策定、産地レベルの集荷・出荷計 画などの生産物管理、生産現場における栽培管 理技術の適期施用など、異なるレベルの意思決 定を支援するために利用される。用いられる手 法は、目的や対象スケールによって様々である が、その基本概念によって次の二種類に大別で きる。一つは、実際の収量（実収量）を標準的 条件で得られる平均収量とその変動要因との和 で表すという考え方である。これには、回帰分 析に代表される統計的手法が利用される（以下、 統計的モデル)。統計的モデルは、過去の収量 変動と気象条件との関係の解析に有用で、頻繁 に利用されてきた。たとえば、Lobellら ${ }^{(1)}$ が 1980年からの約 30年における気候変動がトウ モロコシ、イネ、コムギ、ダイズの収量に及ぼ した影響を調查した結果によると、コムギ、ト ウモロコシでは、すでに温度上昇による負の影 響が認められ、この間の気候変動は、コムギで $3.8 \%$ 、トゥモロコシで5.5\%、生産を低下させ る影響があったものと推定された。しかしなが ら、統計モデルでは、過去のデー夕範囲を超え るような中長期的な予測には、十分な根拠を持 たない。

もう一つの方法は、実収量を、潜在収量（養 水分の過不足、病害虫、倒伏などの生育阻害が 


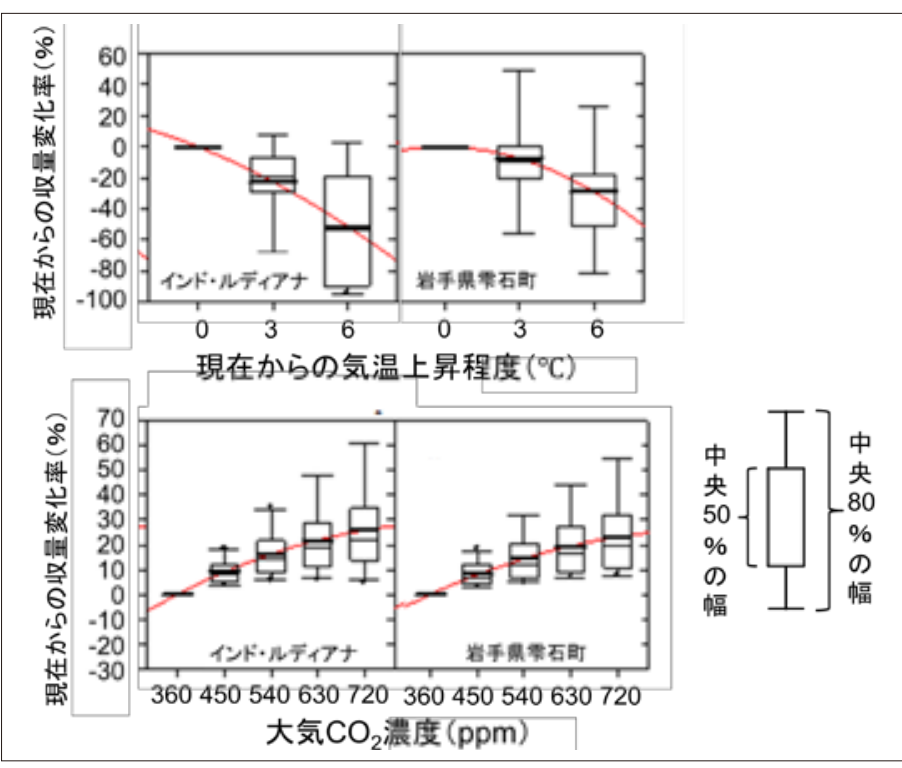

図 1 イネの温度・ $\mathrm{CO}_{2}$ 濃度上昇に対する予測収量の作物モデ ルによる違い。

国際的な農業モデルの相互比較・改良プロジェクト (AgMIP、 気候学、作物学、経済学などの分野を結び付けて、気候変動 が農業や食料安全保障に及ぼす影響を明らかにするための国際 的な研究プロジェクト。http://www.agmip.org/) において、 イネの生育・収量を予測する 13 モデルの温度および大気 $\mathrm{CO}_{2}$ 濃度に対する収量反応を比較。その結果、13モデルを平均し た場合 (曲線)、温度上昇に対しては減収 (左)、 $\mathrm{CO}_{2}$ 濃度上 昇に対しては増収（右）すると推定されたが、個々のモデルの 予測值には、大きな幅 (2)。

ない条件で、気候のみからみた達成可能収量） が、種々の生育阻害によって制限された結果と みるもので、気候変動による影響を考慮した将 来のシミュレーション収量予測では頻繁に利用 される。本手法は、収量を生育に伴う作物体の 重量増加、収穫器官への分配といった生育プロ セスの結果として表すため、プロセス積み上げ 型モデル（以下、プロセスモデル）と呼ばれ る。また、統計的モデルが各種の環境要因から 最終の収量を予測する静的モデルであるのに対 し、プロセスモデルは、日々の成長速度を算出
し、それを積分することによって成長 量および収量を求めるため、動的モデ ルに分類される。一般に、プロセスモ デルは統計的モデルに比べて複雑で、 多くのパラメータを要するが、収量成 立の道筋を捉えやすいといった利点が ある。ただし、複雑なモデルの方が予 測精度が高いという訳ではない。近年 実施されたプロセスモデルの相互比較 において、世界のイネプロセスモデル 13 を用いてインドと日本などでの収 量を予測した例 ${ }^{(2)}$ では、13モデルの 平均予測収量は、低緯度のインド・ル ディアナでは温度上昇に伴って減収す る傾向にあるのに対し、寒冷地の岩手 県需石町では、 $3^{\circ} \mathrm{C}$ 上昇程度までは減 収は認められず、それ以上で減収する 傾向にあった（図1）。これは、気候 変動に関する政府間パネルが第5次報 告書 ${ }^{(3)}$ で取りまとめた傾向と類似している。 ただし、13モデルの予測には極めて大きな幅が 認められたことから、温度に対する収量応答の 予測に招ける不確実性は大きく、その要因解明 が必要であることがわかった。

\section{3. 環境操作実験および屋外の 観測から学ぶこと}

作物の環境応答を研究する上では、温度や $\mathrm{CO}_{2}$ 濃度を人為的に改変して、作物の生理、生 
育、収量の反応を知るための環境操作実験が不 可欠である。環境操作実験の結果は、作物モデ ルの基本構造を決定するためだけでなく、モデ ルの精度を検証するためにも利用される。モデ ル開発と環境操作実験は、まさに将来の気候変 動影響を予測する上での車の両輪である。

初期の環境操作実験は、主に閉鎖環境で温度 や $\mathrm{CO}_{2}$ 濃度を制御するものであったが、1990年 以降は屋外の開放系の群落条件で将来の高 $\mathrm{CO}_{2}$ 環境を実現する開放系大気 $\mathrm{CO}_{2}$ 増加（Free-Air $\mathrm{CO}_{2}$ Enrichment、FACE) 実験などが世界各地 で実施されるようになった。日本ではイネを対 象としたFACE実験が1998年に岩手県需石町 で開始し、2010年からは茨城県つくばみらい市 に場所を移し継続している（図2）。大気 $\mathrm{CO}_{2}$ 濃 度を高めた場合、一般に光合成は促進され、乾 物生産ひいては収量も増加する。実際、岩手県 零石町で 7 年、茨城県つくばみらい市で 4 年実 施したFACE実験においても、両地点で共通 して用いた品種「あきたこまち」の収量は、高 $\mathrm{CO}_{2}$ （外気よりも $200 \mathrm{ppm}$ 高めた）処理によっ て平均で $11 \%$ 増加した。しかしながら、その 程度は年次によって0〜 $21 \%$ の間で変動し、冷 害年には増収が認められず、その他の年次では 増収するものの、その程度は高温になるととも に低下した ${ }^{(4)}$ 。さらに、つくばみらいFACE の実験からは、高 $\mathrm{CO}_{2}$ 濃度処理は、高温で頻発 するようになった白未熟粒の発生を助長するこ と、その程度は、高温年により著しいことがわ かった ${ }^{(5)}$ 。以上の結果は、 $\mathrm{CO}_{2}$ 濃度と高温が複

\section{PROFILE}

長谷川利拡

（はせがわ としひろ）

国立研究開発法人農業環境技術研究 所 大気環境研究領域 上席研究員 専門 : 作物学
合的に作物の収量・品質に影響することを示す 実例である。 $\mathrm{CO}_{2}$ 濃度と高温による複合的な影 響のメカニズムの一つに、高 $\mathrm{CO}_{2}$ が及ぼす群落 温度への影響がある。すなわち、高 $\mathrm{CO}_{2}$ 濃度は 光合成を促進する一方で、葉の気孔を閉じ気味 にして蒸散を低下させる。その結果、植物の水 消費は抑えられるが、植物の群落温度は上昇す る。このことが、高温ストレスを悪化させる要 因となる。実際、FACE 実験と群落温度を高め た実験でも確認されつつある。

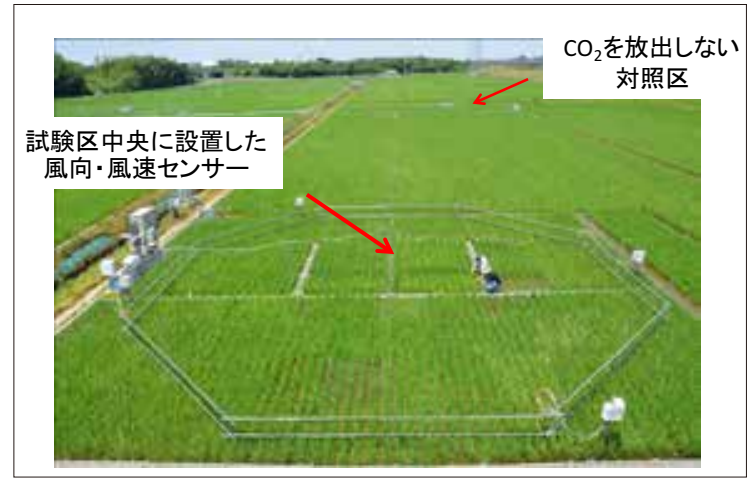

図2 水田におけるFACE (Free Air $\mathrm{CO}_{2}$ Enrichment: 開放系大気 $\mathrm{CO}_{2}$ 増加）実験

屋外条件で高 $\mathrm{CO}_{2}$ 濃度を実現するため、水田の一 画に正八角形状にチューブを設置し、風向きに応じ て風上側から $\mathrm{CO}_{2}$ を放出して、正八角形の区画内 のCO 2 濃度を、対照区より約200ppm高い濃度 (生 育期間平均で約590ppm）に制御する。茨城県つ くばみらい市 (4)。 
この他にも、気温ではなく、群落温度が重要 な役割を持つことは、屋外条件における作物の 高温ストレスでも実例がある。温度に対する感 受性が高い開花期に $35^{\circ} \mathrm{C}$ を超えるような高温 に遭遇すると、生殖過程に障害が発生し、減収 を引き起こすことが知られている。しかし、た とえば、日中の気温が $40^{\circ} \mathrm{C}$ を超える厳しい高温 が頻発するオーストラリアの稲作地帯では、温 度の割に深刻な高温障害の発生が報告されてい ない。これには、当地の低湿度、強風、多日射 といった蒸散が極めて大きくなるような条件が 関係している。こうした気象条件の下では、蒸 散冷却によって群落表面温度は気温よりも $7^{\circ} \mathrm{C}$ 近く低下することがわかった ${ }^{(6)}$ 。一方、多湿 で風が弱い中国長江中流域では、気温が32 $33^{\circ} \mathrm{C}$ であっても、高温に伴う稔実低下が観察さ れている ${ }^{(7)}$ 。このときの穂の温度は、気温よ りも $3^{\circ} \mathrm{C}$ 程度も高かった。これらの結果は、気 候変化の影響を的確に評価し、それを回避する ための技術を開発する上では、群落の物理環境 の変化を正確にとらえることが不可欠であるこ とを示している。

群落の物理環境は、作物の形態（植物の茂 り方、葉の角度など)、生理機能（葉の蒸散能 力）といった植物側の要因と日射、風速、湿度、 $\mathrm{CO}_{2}$ 濃度といった気温以外の気象要素との相互 作用に大きく依存する。室内実験による作物の 温度反応を、屋外の予測に利用する際には、こ うした群落の温度環境を考慮することが必要で あるが、そのためには大気と群落の熱、水収支
を考慮した物理的プロセス、作物の形態形成、 光合成、蒸散といった作物の生理学的プロセス を組み合わせて予測するモデルアプローチが必 要になる。このような作物の形態と群落の物理 環境を取り入れたモデルの開発により、群落内 の気温や湿度環境といった病害の発生に密接に 関わる要素を推定することも可能になり、将来 の病害発生予測にも役立つものと期待される。

\section{4. 融合的なアプローチへの期待}

今後、地球規模での気候の変化や異常気象の 頻発が懸念される中、それらが作物生育に及ぼ す影響を予測し、適応のための品種開発を行う 上で、環境要因と遺伝的要因が作物の生育・収 量・品質に及ぼす影響の解明は中心的な研究課 題である。しかし、これまで環境要因と遺伝的 要因は、作物学、農業気象学、育種学分野にお いて個別に取り組まれることが多かった。

作物学分野や農業気象学分野では、環境要因 が作物に及ぼす影響を物理的あるいは生理過程 に着目して実験的に解明し、予測するためのプ ロセスモデルの開発が進められてきた。プロセ スモデルでは品種の違いは、経験的に求めた品 種固有值によって表されているに過ぎず、遺伝 的な背景との関連は不明なままである。一方、 遺伝育種学においては、遺伝子型の違いが生育 に及ぼす影響が主眼で、環境要因によって変動 する生育への影響は、十分に取り扱われていな い。遺伝子解析技術が大きく進んだ今日でも、 
遺伝子型と環境要因の相互作用は未解明の部分 が多く、限られた環境条件で得られた表現型の 解析のみから、環境応答に関わる遺伝子型の作 用を特定することは困難な状況にある。

これに対し、作物学・農業気象学で進められ てきたプロセスモデルと急激に蓄積されつつあ る遺伝子情報とを融合することにより、環境と 遺伝子の相互作用の解明が大きく進むことが期 待される。この分野での融合的な研究は、すで に比較的単純な形質で開始している。たとえば、 Nakagawa et $\mathrm{al}^{\left({ }^{(8)}\right.}$ は、イネの出穂期の気温や 日長に対する反応について、発育ステージ予測 モデルのパラメータを遺伝解析することによっ て、温度や日長に対する反応に関する QTL（量 的形質遺伝子座）を検出し、品種のQTL情報 と温度、日長条件から、農業形質として重要な 出穂日を予測する可能性を示した。今後、こ うした手法を、収量や品質といったより複雑な 量的形質に適用するためには、遺伝情報解析と プロセスモデルを融合させ、表現型に及ぼす遺 伝的要因と環境要因の影響を物理的・数学的に 記述表する研究手法が必要である。これによっ て、ゲノム情報から、将来の気候条件における 作物生育を予測するとともに、好ましい特性を 持つ品種をデザインすることができるかもしれ ない。さらに、長期的な土䁃肥沃度、施肥管理 の影響と組み合わせることで、気候変動条件で の安定生産に寄与する土㙵管理、栽培技術の開 発が前進する。そのためには、環境と遺伝子型 の相互作用を國場条件下で理解するための実験
拠点の確保、物理的・数学的センスで複雑現象 の解明に取り組む人材ならびに複合的分野を主 導できるような人材の育成が必須である。

\section{参考文献}

1. Lobell DB, Schlenker W, Costa-Roberts J (2011) Climate trends and global crop production since 1980. Science 333:616-620.

2. Li T, et al. (2015) Uncertainties in predicting rice yield by current crop models under a wide range of climatic conditions. Global Change Biology 21:1328-1341.

3. Porter JR, et al. (2014) Food security and food production systems. Climate Change 2014: Impacts, Adaptation, and Vulnerability. Part A: Global and Sectoral Aspects. Contribution of Working Group II to the Fifth Assessment Report of the Intergovernmental Panel of Climate Change, eds Field CB, et al. (Cambridge University Press, Cambridge, United Kingdom and New York, NY, USA), pp 485-533.

4. Hasegawa T, et al. (2015) Rice Free-Air Carbon Dioxide Enrichment Studies to Improve Assessment of Climate Change Effects on Rice Agriculture. Improving Modeling Tools to Assess Climate Change Effects on Crop Response, eds Hatfield JL, Fleisher D (American Society of Agronomy, Madison, WI USA), in press. Doi:10.2134/ advagricsystmodel7.2014.0015

5. Usui $Y$, et al. (2015) Rice grain yield and quality responses to free-air $\mathrm{CO}_{2}$ enrichment combined with soil and water warming. Global Change Biology in press. Doi: 10.1111/ gcb.13128.

6. Matsui T, et al. (2014) Lower-than-expected floret sterility of rice under extremely hot conditions in a flood-irrigated field in New South Wales, Australia. Plant Production Science 17:245-252.

7. Tian X, et al. (2010) Heat-induced floret sterility of hybrid rice (Oryza sativa L.) cultivars under humid and low wind conditions in the field of Jianghan Basin, China. Plant Production Science 13:243-251.

8. Nakagawa $\mathrm{H}$, et al. (2005) Flowering response of rice to photoperiod and temperature: a QTL analysis using a phenological model. Theoretical and Applied Genetics 110:778-786. 